\title{
Challenges on Obtaining Legal Protection Through Notary Honorary Council for the Notary Presumed to Commit Crime
}

\author{
Juleni*; Albertus Sentot Sudarwanto \\ Faculty of Law, University of Sebelas Maret, Indonesia \\ Email: lenisgn@gmail.com
}

http://dx.doi.org/10.18415/ijmmu.v5i2.350

\begin{abstract}
The current study aimed at discovering the notary' challenge during their attempt at obtaining legal protection when facing an allegation of committing criminal activity. In carrying out their duty as a public officer who is authorized to make authentic deed and other authorities under the law, Notary needs to obtain legal protection for the sake of legal certainty and legal service function. The current study could be classified as an empirical legal study. This study employed primary and secondary data collected from interviews and document analysis. The collected data were analyzed by using an interactive model of qualitative analysis technique. Based on article 66 paragraph (1) of Law of The Republic of Indonesia No. 2 of 2014 about the changes to the law number 30 of 2004 regarding position of notary, it has been regulated that for judicial process, investigators, public prosecutors, or judges shall obtain the consent from The Notary Honorary Council to perform an investigation towards a Notary. Notary Honorary Council is an institution that borns to provide legal protection towards a Notary. Especially Regional Notary Honorary Council who is authorized in this case, by its panel of Inspector. However, in fact, there are several factors which make notaries had not felt optimal legal protection from the Regional Notary Honorary Council.
\end{abstract}

Keywords: Legal Protection; Notary; Notary Honorary Council; Board of Inspector

\section{Introduction}

Indonesia as a nation of law (rechstaat), needs a professional and highly moral notary. As a public officer, notary public holds essential role and function to embody a dignified and sovereign country with nuances of legal certainty (Sri Utami., 2015: 89). A notary is a public officer appointed by the government for broad community' importance. The service provided by the notary closely related to the matter of trust, in other words, the State leaves a big trust on a notary (R.A. Emma Nurita., 2012: 2). The institution of Notary is established by the state (Bagir Manan., 2004: 15), to carry out some parts of the state' authority in the field of civil law, by making an approved written item of evidence, consequently, the function of Notary is allowed to use the symbol of the state in carrying out its function. The state is also responsible for providing legal protection towards a notary. 
Article 1 number 1 of Law number 2 of 2014 about the changes to the law number 30 of 2004 concerning the position of a notary (hereinafter referred to as Law no. 2 of 2014) states that Notary is a public official who is authorized to make an authentic deed and have more authority as referred to in this Act or under other laws. A public officer is a person who carries out a part of the public function of a state, particularly in the field of civil code (Hartanti Sulihandari dan Nisya Rifiani., 2013: 5). The Notary' authority as a public officer is regulated in the article 15 paragraph (1) of Law No. 2 of 2014 which states that: "Notary Deed authentic authority on all deeds, agreements, and determination required by legislation and/ or desired by stakeholders to be declared in an authentic deed, deed of guarantee certainty the date of manufacture, save Deed, giving grosse, copy and quote Deed, Deed of making it all along it was not also assigned or excluded to other officials or other persons specified by law".

Notary Deed rises because of direct involvement of the parties appear before the notary, they are the main actors of the authentic deed process making. The Notary deed authentically spells out the deeds, agreement, and determination witnessed by the appearers and the witnesses (Wawan Tunggal Alam., 2001: 85). Every carrying out their duty in making a deed, notaries are responsible for their deed as it is the realization of parties' eagerness in the form of an authentic deed. Follow-up on the duty carried by Notary possesses legal consequences, in other words, Every Notary deed can be an item of evidence. If there is a dispute between the parties, the notary could be involved. For this involvement, Notary shall be responsible for what they have been done. The Judge holds a sole authority and decision over a dispute, therefore, Judge holds the right to assess about what and how the deed is disputed (Kohar., 1983: 28).

The root of problems may arise directly from the Notary' mistakes or indirectly from other people (client) (Sri Utami., 2015: 89). A notary may perform mistakes in making a deed. If this mistake is proven, such deed loses its authenticity and legally void, or can be annulled. A notary is prone to law problems, because of the internal factor from themselves such as carelessness, procedure disobedience, professional ethics violation, and so on. Besides, internal factor such as the community' moral where Notary is faced on the fake documents where such documents contain legal consequence for its owner (Pengurus Pusat Ikatan Notaris Indonesia., 2008: 226). In this case, if it harms the parties concerned with such deed, Notary can be sued either in criminal or in a civil manner. The criminal sanction is given in the form of criminal sentence, and the civil sanction is given in the form of giving a compensation towards the concerned party (Tan Thong Kie., 2007: 149).

Notary needs legal protection which capable of ensuring their safety in carrying out their function. As it is stated in article 66 paragraph (1) of Law No. 2 of 2014, the authority held by The Notary Honorary Council (hereinafter referred to as MKN) is to be an Institution of legal protection for notaries. If a notary is presumed to do a mistake or violation in making a deed, the law enforcer apparatus shall request MKN' consent to summon notary for asking for information. As the follow up for the regulation of article 66 of Law No. 2 of 2014 regarding MKN, Regulation of Minister of Justice and Human Rights No.7 of 2016 about Notary Honorary Council (hereinafter referred to as Permenkumham No. 7 of 2016).

Article 1 number 1 of Regulation of Minister of Law and Human Rights No. 7 of 2016 states that: "Notary Honorary Council is an institution holding an authority to perform guidance to the Notary and providing approval or rejection for the sake of judicial process, for the taking of photocopy of minutes of deed, and the call on the notary to attend the investigation on the things within the notary' storage". MKN comprises Central Notary Honorary Council (hereinafter referred to as MKNP) and Regional Notary Honorary Council (hereinafter referred to as MKNW). MKNP must carry out guidance and supervision towards MKNW regarding its duty. MKNW is authorized to give consent or rejection towards the request of summoning a notary for an investigation.

Permenkumham No. 7 of 2016 does not explicitly assert in its articles whether the nature of MKNW' decision is final and binding. This minister regulation accounts that the duty of MKNP is limited 
to perform guidance and supervision towards MKNW, and is not explained whether or not MKNP holds the authority to accept the objection legal attempt from the Notary who is sentenced by MKNW. This leads to uncertainty and unclarity whether or not the Notary may file an appeal against MKNW decision which states that the law enforcer apparatus may summon the notary for further investigation.

In Permenkumham No. 7 of 2016, there is also legal gap regarding the absence of regulation on the Notary' legal objection against MKNW' decision on the summoning of the Notary if that decision is not under the regulation. It is not elucidated whether or not MKNP is able to accept Notary' appeal request against MKNW' decision that is considered as harming him/her. Regarding the determination of Article 66 paragraph (3) and (4) of Law No. 2 of 2014 which state that if MKNW within 30 (thirty days) since the request letter is received, does not give an answer, MKNW is assumed as approve the request and the notary shall attend the summoning. Such regulation may arise an injustice for the notary, where MKNW who is expected to protect the Notary, on the contrary, harms the Notary by that regulation.

About the clarification process towards the Notary by the Panel of Inspector, it is not found whether the Notary can use the right of refusal during the inspection process since the deed made by the notary is the right of the parties whose secret shall be kept by the Notary concerned. Article 4 paragraph (1) of Permenkumham No. 7 of 2016 explains that MKNW comprises the element of:

1. Government;

2. Notary;

3. Expert or Academician

The element of MKNW is not merely Notary. It consists of government and expert or Academician. Consequently, a notary under the investigation of the Board of investigator supposed to be allowed to use right of refusal since the member of MKNW from government or expert or Academician may not have understood the notarial regulations. This kind of case supposed to be regulated in the issued regulation since it affects an essential thing regarding protection for the Notary. Moreover, the investigator, in carrying out its duty on the Notary who is presumed violating UUJN is also found possessing insufficient competency about the authority of MKN. Based on the problems described above, this paper aimed to discuss how legal protection for the Notary from MKN when facing a presumption of a criminal act based on Permenkumham No.7 of 2016.

\section{Methodology}

This study was an empirical legal law, a legal study which employs secondary data at the beginning, and then is followed by primary data or field data. The data were collected through library study on the legislation, journals, or related references and interviews with the member or MKN.

\section{Results and Discussion Review on Notary and Notary Deed}

In Indonesia, Notary profession began in the first 17th century by the existence of Oost Indische Compagnie, the combination of The Netherlands' corporation in east Hindi known as VOC (Verenigde Oost Indische Compagnie) with a man named Jan Pieter Zoon Coen as its Governor-General. He appointed Melchior Kerchem as the first Notary in Jakarta on 27 August 1620. Melchiom Kerchem served all types of letter, privately made testamentary disposition, preparation of enlightenment, sell and purchase deed, marriage agreement, disposition letter and other deeds and other regulations needed from the city service and so on (Hartanti Sulihandari dan Nisya Rifiani., 2013: 8). In 16 June 1625, after the 
function of "Notary public" was divided from "secretaries van den garechte" function by the Governor General' letter of decision of 12 November 1620, the first instruction for notaries in Indonesia was issued, it contained only 10 (ten articles) one of those was a stipulation that a Notary had made a vow and been tested.

Notary in Indonesia experienced development along with Indonesia' development. After Indonesia declared its independence on 17 August 1945, the existence of Notary in Indonesia was still admitted based on article II of Regulation of Transition of 1945 Constitution that stated: "All existing regulation of legislation is still in force as long as there have not been a new one under this constitution". On 6 October 2004, Law No.30 of 2004 about the Position of Notary or is called as UUJN was issued. It was the only law regulating the function of Notary in Indonesia (Habib Adjie., 2009: 1-4). UU No. 30 of 2004 is the instance of Regulation of Notarial Function and Reglement op Het Notaris Ambt in Indonesia which was regulated by Colonial government of the Netherlands (Hartanti Sulihandri dan Nisya Rifani, 2013: 9). Then, Law number 2 of 2014 about the Changes on UU No.30 of 2004 about the Position of Notary was born.

Article 1 number 1 of Law No. 2 of 2014 states "Notary is a public official who is authorized to make an authentic deed and have more authority as referred to in this Act or under other laws". Article 1868 of Civil Code States that "An authentic deed is one which has been drawn up in a legal format, by or before public officials who are authorized to do so at the location where this takes place". If that regulation is not met, such deed only becomes a private document as it is regulated in article 1869 of Civil Code. Based on the description of article 1868 of Civil Code, it contains an understanding that a deed is considered as authentic if it is made in the form regulated by the constitution and is made by a public officer authorized to do it.

Notary as a public officer is a professional whose information is trustworthy, its signature and seal are capable of providing warranty as a robust item of evidence, and an independent party in providing valid legal information (Endang Purwaningsih., 2011: 324). Article 15 paragraph (1) of Law No. 2 of 2014 states that Notary' authorities are: "Notary Deed authentic authority on all deeds, agreements, and determination required by legislation and/ or desired by stakeholders to be declared in an authentic deed, deed of guarantee certainty the date of manufacture, save Deed, giving Grosse, copy and quote Deed, Deed of making it all along it was not also assigned or excluded to other officials or other persons specified by law".

Other authorities held by the Notary in addition to the above mentioned are the authority under article 15 paragraph (2) of Law No. 2 of 2014, as follow:

a) To validate the signature and establish certainty under the date of the hand by enrolling in a special book;

b) To post a private letter by registering in a special book;

c) To make a copy of the original private letter in the form of a copy of which contains a description as written and illustrated in the letter in question;

d) To confirm the compatibility between the photocopied and the original letter;

e) To provide legal information regarding the making of a deed;

f) To make a deed related to lands; 
g) To make auction treatise deed

A notary is authorized to make a deed which can be an authentic written item of evidence within a case. The constitution and law, court order and agreement between the parties, determine notary public service. According to the type of notarial acts, the jurisdiction of notary public is determined by the law, court order-court document and optional-logic, according to the initiative of the party. Law provides notary jurisdiction, and it applies to its work (Trgovêević Prokić Milena., 2011: 140).

According to C. A. Kraan, an authentic deed possess the following characteristics:

1) The Writing is intentionally made to be evidence or proof of an event as it is stated in the writing and is stated by an authorized officer. That writing is signed by or is only signed by the officer concerned;

2) The writing, until it is proven otherwise, is assumed as issued by the authorized officer;

3) The regulation of legislation shall be obeyed; such regulation regulates the procedure of its making (at least contains regulation regarding the date, the place where the deed is made, name and the function or the position of the officer who makes it);

4) An officer appointed by the state and possessing an independent and impartial behavior and performance in carrying out their function;

5) A statement or a fact of action stated by the officer is the legal relationship within the field of private law (Herlien Soerojo., 2003: 148)

\section{Review of the Notary Honorary Council and the Panel of Inspector}

Notary Honorary Council is an institution whose existence and function is elucidated in article 66 of law No. 2 of 2014 which states that:

1) For the sake of judicial process, the investigator, the public prosecutor, and the judge, by the approval of the Notary Honorary Council, are authorized to:

a. Take the photocopy of minutes of the deed and the letters attached to the minutes of the deed and the Notary' protocol within the Notary' storage; and

b. Summon the Notary to attend the investigation related to the Deed or the Notary' protocol within the Notary' storage.

2) The taking of photocopy of minutes of the deed or the letters meant in paragraph (1) letter a, need a transfer minute.

3) The Notary Honorary Council no later than 30 (thirty) work days since receiving the letter of request as it is meant in the article (1) shall give an answer either approve or reject the request.

4) If the Notary Honorary Council does not give an answer within the period meant in the article (3), the Notary Honorary Council is assumed approving the request.

As the follow up for the regulation of article 66 of Law No. 2 of 2014, Minister of Law and Human Right of Indonesia issues the Regulation of Minister of Law and Human Right of the Republic of 
Indonesia no. 7 of 2016 about the Notary Honorary Council. Article 1 paragraph (1) of Permenkumham No. 7 of 2016 about the Notary Honorary Council states that: "Notary Honorary Council is an institution holding an authority to perform guidance to the Notary and providing approval or rejection for the sake of judicial process, for the taking of photocopy of minutes of deed, and the call on the notary to attend the investigation regarding the notary' deed or protocol within the notary' storage".

Article 2 paragraph (1) of Permenkumham No. 7 of 2016 about Notary Honorary Council states that the structure of Notary Honorary Council is:

1) Central Notary Honorary Council (MKNP);

2) Regional Notary Honorary Council (MKNW)

Article 12 of Permenkumham No. 7 of 2016 states that in carrying out its duty, MKN is assisted by the Board of Investigator and the Secretariat of MKN.

Besides, in article 21 paragraph (1), it is also stated that:

"(1) In performing investigation towards a Notary, The Chairman of the Regional Notary Honorary Council forms the Board of Investigator with 3(three) members consisting of every element of the member of Regional Notary Honorary Council". MKNW is authorized to give approval or rejection against the request of summoning Notary to attend the investigation conducted by the law enforcer and the request approval of picking up the photocopy of minutes of the deed and/ or letters attached on the minutes of the deed or Notary' protocol within the Notary' storage. This is asserted in article 21 paragraph (5) of Permenkumham No. 7 of 2016 which states that: "The Panel of Investigators is authorized to investigate and to provide approval or rejection against the investigators, public prosecutors, or judges regarding the taking of photocopy of minutes of deed and letters attached on the minutes of deed and/or the Notary' protocol within the Notary' storage".

In performing investigation towards a Notary, the Chairman of MKNW forms a Panel of Investigators consisting of 3 (three) members. They are authorized to investigate and give approval or rejection against the investigators', public prosecutors', or judge' request regarding the taking of photocopy of minutes of the deed and/ or Notary' protocol within the Notary' storage and summoning Notary. Every result of the investigation conducted by the Panel of Investigator is reported to the Chairman of MKN which will be sent to the Chairman of MKNP as a monthly report.

Article 4 paragraph (1) of Permenkumham No. 7 of 2016 explains that MKNW consists of the element of:

1) Government;

2) Notary;

3) Expert or Academician

The members of MKNW are seven people consist of:

1) 1 (one) chairman;

2) 1 (one) vice chairman;

3) 5 (five) members

The chairman and the vice chairman of MKNW must come from the different elements as well as MKNP. The members select the chairman and the vice chairman of MKNW through discussion. If discussion cannot reach an agreement, the selection is done by voting. This is asserted in article 4 of Permenkumham No. 7 of 2016. 
Article 25 paragraph (1) of Permenkumham No. 7 of 2016 asserts that the panel of Investigators provides approval or rejection after listening to the testimony from the Notary concerned directly. The criteria to give approval or rejection must be measurable and logically acceptable and must be in line with the legal fact that exists. For the Notary who face a presumption of committing a criminal act and is called to be asked for information, shall be cooperative with the panel of Investigator formed by MKNW. The notary is expected to fulfill such calling since, if the notary has been legally and properly summoned twice consecutively and do not present, the Panel of Investigators may utilize its authority to make a decision of approval or rejection against a request form the investigators, public prosecutors, and judges. Such decision made by the Panel of Inspector may harm the Notary concerned.

The procedure of conducting inspection against a notary if the law enforcers file a request of calling a notary to MKNW is as follow:

\section{a. Filing a Request}

On article 23 paragraph (1) of Permenkumham No. 7 of 2016, it is stated that:

"the request of the taking of minutes of deed or Notary' protocol and a calling for the Notary by the investigator, public prosecutor, or judges to attend the investigation regarding the deed or Notary' protocol within a Notary' storage is filed to the Chairman of MKNW in consonance with the work region of the Notary concerned".

That request is filed in written in Bahasa Indonesia and is copied to the Notary concerned. The writing procedure of calling request is stated in the article 23 paragraph (3) of Permenkumham No. 7 of 2016, it comprises of:

1) Notary' name;

2) Notary' office address;

3) Number of Deed and/ or letter attached to the minutes of the deed or the Notary' protocol within the Notary' storage;

4) Merits of the presumed case

\section{b. The formation of Panel of Inspector}

After the law enforcers file a request to MKNW, MKNW forms a panel of Inspector as it is mentioned in article 21 paragraph (1) of Permenkumham No. 7 of 2016. The formation of Panel of Inspector is done not later than 5 (five) work days since the report is received.

Article 22 of Permenkumham No. 7 of 2016, states that:

1) The panel of Inspector as meant by article 21 must reject to inspect a notary who possesses marriage and blood relationship within a lineage by vertical line without limitation of civil degree, and within a horizontal line until the third civil degree;

2) If the Panel of Inspector possesses a relationship meant by the article (1), the chairman of MKNW appoints a substitute. 


\section{c. The Calling on Notary by the Panel of Inspector}

Article 24 paragraph (1) of Permenkumham No. 7 of 2016 states that the Panel of Inspectors is authorized to call a notary based on the request from the investigator, public prosecutor, or judge, the calling on Notary is carried out through a letter signed by the chairman of MKNW. In urgent circumstances, the calling can be done through facsimile and/or electronic mail which is followed by the letter of calling immediately.

The calling to the Notary is done no more than 5 (five) work days before the inspection is performed. The notary must attend the calling from the Panel of Inspector and may not be represented. As it is stated in article 24 paragraph (6) of Permenkumham No. 7 of 2016, if a notary does not attend after being legally and properly summoned twice consecutively, the panel of Inspector may make a decision towards the law enforcer' request. In performing inspection, the Panel of Inspectors is assisted by 1 (one) secretary.

\section{d. The Inspection' Finding}

Article 23 paragraph (4) of Permenkumham No. 7 of 2016 explains that "the Chairman of Regional Notary Honorary Council must provide an answer in the form of approval or rejection against a request within 30 (thirty) work days since the request is received". If that period is exceeded, it is assumed that MKNW accepts the request of call on the Notary, which has been explained in article 23 paragraph (5) of Permenkumham No. 7 of 2016. Article 25 paragraph (1) of Permenkumham No. 7 of 2016 which states that the panel of Investigators provides approval or rejection after listening to the testimony from the Notary concerned directly.

Every inspection' finding of the Panel of Inspector is reported to the Chairman of MKNW to be sent to the Chairman of MKNP every month. It is stated in article 21 (21 paragraph (6) of Permenkumham No. 7 of 2016, MKNW as an Institution which provides legal protections to the Notary shall care and be responsive to the request from the investigators, public prosecutors, and judges who file to perform an inspection against the notary, it is expected to not exceed 30 (thirty) days period without conducting a call to the notary concerned since it will be harmful to the notary concerned.

\section{Conclusion}

A phrase "by the approval of Notary Honorary Council" means that the calling to a Notary cannot be performed without MKN' approval It shows an attempt of legal protection towards a Notary and this regulation only works for the criminal case since the regulation state the authority of investigator, public prosecutor, or judge. Based on article 24 paragraph (5), Notary must attend the calling from the Panel of Inspector and may not be represented. Article 24 paragraph (6), if a notary does not attend after being legally and properly summoned twice consecutively, the panel of Inspector may make a decision towards the request of the investigator, public prosecutor, or judge. Article 24 paragraph (6) has mandated a wide authority towards the panel of Inspector, either to approve or to reject the investigator' request with a reason that the Notary may not attend the call from the Panel of Inspector.

It is the Notary' personal choice if the notary prefers to face the call from the Panel of Inspector and declare to use its' right of refusal, as long as the law does not except it. If the notary believes that they have not needed to use the right of refusal, they do not need to use it. If MKNW approves the investigators', public prosecutors, and judges' request so that the notary attend the call, the notary is still 
able to declare its' right of refusal. When notary uses its rights of refusal before the panel of inspector, so the panel of inspector only need to note in the investigation record that notary uses its right of refusal.

\section{References}

A. Kohar. (1983). Notaris Dalam Praktek Hukum. Bandung: PT. Alumni.

Bagir Manan. (2004). Hukum Positif di Indonesia. Yogyakarta: UII Pers.

Endang Purwaningsih. (2011). "Penegakan Hukum Jabatan Notaris Dalam Pembuatan Perjanjian Berdasarkan Pancasila Dalam Rangka Kepastian Hukum”. Jurnal Hukum Adil, 2(3): 324.

Habib Adjie. (2009). Sanksi Perdata dan Administratif Terhadap Notaris sebagai Pejabat Publik. Bandung: Refika Aditama.

Hartanti Sulihandari dan Nisya Rifiani. (2013). Prinsip-Prinsip Dasar Profesi Notaris. Jakarta Timur: Dunia Cerdas.

Herlien Soerojo. (2003). Kepastian Hukum Hak Atas Tanah di Indonesia. Surabaya: Arkola.

Pengurus Pusat Ikatan Notaris Indonesia. (2008). Jati Diri Notaris Indonesia Dulu, Sekarang dan di Masa Datang. Jakarta: PT. Gramedia Pustaka.

R.A. Emma Nurita. (2012). Cyber Notary Pemahaman Awal Dalam Konsep Pemikiran. Bandung: Refika Aditama.

Sri Utami. (2015). "Perlindungan Hukum Terhadap Notaris Dalam Proses Peradilan Pidana Menurut Undang-Undang Nomor 2 Tahun 2014 Tentang Perubahan Atas Undang-Undang Nomor 30 Tahun 2004 Tentang Jabatan Notaris". Jurnal Hukum Repertorium, 3(1): 89.

Tan Thong Kie. (2007). Studi Notariat dan Serba-Serbi Notaris, Jakarta: Intermesa.

Trgovĉević Prokić Milena, "Legal Basis of Notary Public Services“, article on International Journal of Economics and Law, 1(3): 140.

Wawan Tunggal Alam. (2001). Hukum Bicara Kasus-Kasus dalam Kehidupan Sehari-hari. Jakarta: Milenia Populer.

\section{Copyrights}

Copyright for this article is retained by the author(s), with first publication rights granted to the journal.

This is an open-access article distributed under the terms and conditions of the Creative Commons Attribution license (http://creativecommons.org/licenses/by/4.0/). 